\title{
Directions of New Music
}

Volume 1 | Issue 2

Article 2

May 2018

\section{"Lehadlik": Radical Jewish Music, Gender and Disidentification in Aviva Endean's Work}

Shoshana Rosenberg

Curtin University

Follow this and additional works at: https://ro.ecu.edu.au/dnm

Part of the Composition Commons, Jewish Studies Commons, Musicology Commons, and the Music Performance Commons

\section{Recommended Citation}

Rosenberg, S. (2018). "Lehadlik": Radical Jewish Music, Gender and Disidentification in Aviva Endean's Work. Directions of New Music (2).

http://dx.doi.org/10.14221/dnm.i2/2

This Article is posted at Research Online.

https://ro.ecu.edu.au/dnm/vol1/iss2/2 


\title{
"Lehadlik": Radical Jewish Music, Gender and Disidentification in Aviva Endean's Work
}

\author{
Abstract \\ This paper undertakes a hermeneutic analysis of Aviva Endean's "Lehadlik", exploring the complex \\ relationship between the player, a Jewish woman living in Australia, and traditional Jewish culture and \\ rituals. This analysis connects Endean's work to the larger body of Radical Jewish Music, a movement \\ which seeks to diversify and expand the meaning of contemporary Jewish music beyond the confines of \\ Klezmer and religious hymns. The analysis includes an exploration of the relationship between Endean's \\ womanhood, Orthodox Jewish traditions, and women's historical place in Judaism.

\section{Cover Page Footnote} \\ I would like to thank Aviva for her generosity in providing me with a wealth of information about the piece \\ and permitting me to write this paper.
}




\section{"Lehadlik": Radical Jewish Music, Gender and Disidentification in Aviva Endean's Work}

\section{Shoshana Rosenberg}

\section{Introduction}

Jewish culture, including music, in recent times appears to be torn between striving for authentic tradition and remaining relevant within technological and sociocultural advancements. In the first instance, proponents of Jewish reconstructionism have sought to create a certain type of authenticity, leaning heavily on historical precedents and cultural artefacts recovered from the ruins of the Sho'ah (Holocaust) (Charme, 2000; Eichler, 1997; Jockusch, 2012; Yerushalmi, 2011). In the realm of music, Jewish reconstructionists have created a very particular image of Jewish music under the banner of klezmer revivalism, ${ }^{1}$ influenced by a particular perception of Judaism's history and roots (Feldman, 2016; Noël, 2010; Rosenfelder, 2012; Stevens \& Steinmetz, 2002; Waligorska, 2013). In response, a movement has developed over the last four decades to counter the strict and arbitrary musical boundaries imposed by Jewish reconstructionists and klezmer revivalists. Radical Jewish Culture (Zorn, 2006), and its musical components, is a philosophical and political counterpoint to the conservatism enacted by reconstructionists and revivalists; it posits Judaism as an identity which continues to grow and evolve. This paper explores Aviva Endean's Lehadlik (2015), how it exemplifies Radical Jewish Music and contributes to the growing body of work that challenges tradition while refusing to abandon it completely.

\section{Klezmeric Monolith}

In present-day mainstream society, what is considered Jewish music is viewed through the lens of centuries-old Ashkenazi and Sephardi traditions; ${ }^{2}$ it is the sound of klezmer music, folk songs and hymns (Rosenfelder, 2012). This perspective has been cemented by the klezmer revival movement, which seeks to

1 Klezmer music is traditional Jewish music originating from Europe, often played at celebrations, typified by the utilisation of the altered Phrygian scale, as well as particular instruments such as the clarinet and the violin (Waligorska, 2013).

2 Ashkenazi and Sephardi (sometimes spelled S'faradi) are the ethnic identities of European Jews, with the latter delineating those who are from Spanish rather than Russian, Hungarian, Polish or other European roots. These groups differ from Mizrahis, Jews of African or other non-European descent (Yanow, 1998). 
counteract the loss of identity, community, and praxis caused by the Sho'ah, through an egalitarian approach to both the playing and appreciation of klezmer music (Jockusch, 2012; Stevens \& Steinmetz, 2002). By disseminating a highlynostalgic, widely-accessible strain of Jewish 'people's music', klezmer revivalists hope to reclaim ancestral threads which have been severed by war, persecution and disaster (Eichler, 1997). Ultimately, klezmer revivalism and similar movements have been utilised as methods of cultural recovery and commemoration which have in turn significantly influenced the way in which modern Judaism is perceived and conducted (Bohlman, 2013; Feldman, 2016; Waligorska, 2013). In doing so, however, this movement has highlighted an evergrowing chasm between the reconstructed simulacra of traditional Jewish music (as most if not all original traces were lost in WWII) and the state of Jewish-led musical creation in contemporary society (Rosenfelder, 2012; Waligorska, 2013).

Walden (2009) argued that in some ways, the monolithic, monopolising nature of the klezmer revival movement has enacted an erasure of significant variations amongst different Jewish communities and their musical output. When Jews were forced into diaspora, so too was their music; as such, their traditional melodies and songs experienced fragmentation and diversity, and slowly became regional rather than collective. However, the revivalist recovery project was incapable of accommodating for such a variation; how can there be Jewish unity with such a divergence in the way Jews lived? And more importantly, how can Jews establish their culture as that worth preserving when Judaism's practices and goals seem so disparate? Klezmer revivalism provided an answer to these questions in the form of simplification; reduce Judaism's associated musical (and non-musical) practices to those most closely emulating the European shtetl, and focus the cantor's song on a return to Zion (Walden, 2009). The reclamation and reimagining of Jewish culture, however, was not the klezmer revivalists' alone.

\section{Radical Jewish Music}

Radical Jewish culture, and its musical accompaniment, has been a steadilygrowing movement over the past few decades, tying contemporary Jewish culture(s) to a broad range of musical expression (Wall, 1999). A major proponent of Radical Jewish music (RJM) has been John Zorn, who took to the task of releasing RJM records through his Tzadik label, both as a means of distributing these ideas further and as a way to provide material explorations of the breadth, depth and diversity of music made under the banner of RJM (Zorn, 2006). RJM is experimental, esoteric, and transformative; it is "musical alchemy" (Zorn, 2007). Zorn is careful to decouple RJM from other 'radical' Jewish movements, in 
particular Zionism. ${ }^{3}$ This, in some ways, may be one of the most fundamental elements of RJM. It is an acceptance of diaspora, and recognition of the Jew as an inter-cultural figure.

Anat Cohen provided a similar sentiment, stating: "I'm working hard to put the clarinet in other scenarios that are not necessarily just folkloric or just traditional. ... I try to bring it to any kind of scenario and find its place" (National Public Radio, 2013). RJM is therefore not about Jewish music finding a home; it is about Jewish music residing wherever each person engaging with it rests their head. Although RJM is not simply music made by Jewish people (Zorn, 2006), in the diaspora of Australia, Jewish artists are producing music which falls within the spirit of RJM. Although many of these artists do not directly identify with RJM, one artist in particular has produced Jewish music which is transgressive, immersive, and radical, and whose output is a significant contribution to the RJM body of work. This article will provide a hermeneutic analysis of one of her works.

\section{Hermeneutics and the Torah}

Hermeneutic interpretation is a pillar of Midrash, or Jewish Talmudic study (Cushman, 2007); ${ }^{4}$ it is a process of witnessing how the Torah opens itself to you, and how you in turn shine a different light on the Torah (Kolbrener, 2004). This cycle of reading and re-reading, writing and re-writing, of "talking" to the text (Stone, 1998, p. 34), remains a crucial aspect of contemporary approaches to both understanding the Talmud and hermeneutic analysis more broadly. By immersing ourselves in the text, we can not only provide a deeper perspective on the text, but also uncover the role that our own presence as readers/analysts/devotees has on it. We both transform and are transformed by texts (Hall, 2009). In this sense, the work discussed below is significantly hermeneutic in its creative and individual engagement with previously established texts.

\section{Aviva Endean (b. 1985)}

Aviva Endean's compositions are a dialectic exploration through dialogue. Her compositions and performances rely on conversations, meaning-making processes which reach toward shared truths, rather than dictating any one given truth. Many of her works involve audience immersion through selective sensory alteration

3 It is important to note that despite Zorn's contribution to RJM, he remains a controversial figure; as a proponent of the 'genius male composer' trope, he contributes to the creative and social exclusion of women and others who do not subscribe to, or fit neatly into, that ideal (McLary, 2000).

4 The Talmud is a collection of canonised Rabbinical commentary and interpretations of the Torah, otherwise known as the Old Testament (Avery-Peck \& Neusner, 2004). 
methods such as eye covers and earplugs. This allows for a more direct set of connections: between the audience and the work; between the performer and the audience; and between the person and their own senses, heartbeat, and breath. One piece in particular, however, allows some insight into a different dialogic interaction.

\section{Lehadlik (2015)}

In Endean's Lehadlik (2015), you are invited to witness a very intimate scene, one usually reserved for familial celebrations and traditional rituals. In the work, Endean is standing in a home, at a dining table set for Shabbat, including two candles, each with a small electronic sensor facing a few inches away from the wick. In the video documentation, the camera is positioned across the table from the player; in live performances, Endean invites people to sit at the table with her. She lights one candle, and an Ashkenazi cantor's incantation of the first text of the Torah emanates from an unseen speaker. She then moves her hand between the flame and the sensor, modulating the cantor's song, causing the words to repeat themselves and tumble over one another. The artist then covers her eyes when the cantor talks about God discerning between light and darkness, in the same way a person traditionally would during the Shabbat ceremony. She then lights the other candle, adding a second incantation, this time by a Sephardic cantor. This recording is different; it is quieter, practically incoherent, and when Endean disrupts the flame's path to the sensor, the voice becomes simultaneously louder and more muffled. These disruptions are then repeated, with Endean's hands moving deliberately, blocking one flame's path and then the other. After some time, she produces a clarinet, and begins to play morose, discordant, circularbreathing tones and melodies, moving between the modes used by the two cantors, while slowly covering one light and then the other with the bell of the instrument. Finally, she extinguishes each of the candles with the air from her clarinet. The ritual is complete.

\section{Interpretation}

\section{The Torah and Itself}

This piece is reminiscent of Talmudic investigation at its highest level. There are four participants in this magical exchange; the audience, the player, the Torah, and the Torah again. The audience is the receiving vessel for these intricate interactions. They experience the total sum of these proceedings, and their magical content. Meanwhile, the two incantations are relentless; they are specific, they are spoken with intention, and they can only be briefly interrupted by the player/reader. Each carries its own meaning, and the passion with which the cantor delivers it only serves to further establish the incantation's importance. 
Endean forces these two chants to clash with each other, and compete for audibility and legibility. However, when she does 'attend' to one or the other, it becomes distorted, uneven. It is as if these words are at their most coherent when they blend together, when they form a bigger body of sound. This has a significant resemblance to the way the Torah is studied today; it must speak to itself to be understood, and that interaction is facilitated by people (Kolbrener, 2004).

As Rojtman (1998) posited, Jewish hermeneutics requires human intervention, a designating act, which moves the text closer to revealing its secrets. Endean's piece invokes this process; two chants, separate but spoken at once, carry a power far greater than if they were simply read and interpreted individually. In doing so, they simultaneously gesture at, but not directly unveil, the codes which they each carry, and their collective meaning. Therefore, Lehadlik replicates the process of Kethib-Qere (Gordis, 1970), wherein the way a passage is written down differs widely to how it is spoken by the Rabbi. Endean plays a vital role here; though the cantor's words were spoken in the way dictated by Kethib-Qere, she again modifies how they are heard. In a way, disrupting a hymn is a radical act, but in another it is simply a new manifestation of traditional interpretative Talmudic practices.

The Torah is a living document, and liberating it through individual song can be seen as pleasing God (Yuter, 2010). Additionally, redaction, reinterpretation and editing is an integral part of the study of the Torah and in comprehending its relevance to the politics and practices of present world (Gohdes-Luhman, 2004; Levinson \& Zahn, 2002; Runions, 2001). Endean's modification of these incantations is therefore not dismissive, nor is it treated lightly. She engages her body with the words being spoken, making material that which is otherwise ethereal, her act of musical and physical reinterpretation forming a new and powerful way to internalise these ancient words. By doing so, she is enacting her own kind of Talmudic interpretation and re-comprehension; this is her Midrash.

\section{Gendering and Politicising the Torah}

Endean's role as a player in this piece is not simply one of exploration and experimental interjection. Women are still viewed as lesser within Jewish orthodoxy, and their presence in the synagogue has to be mitigated by a Mehitzah, ${ }^{5}$ even when they are invited to read the Torah (Cohen \& Ner-David, 2002). Although the Mehitzah is a physical barrier, it is also a psychological and philosophical one, sectioning women out of certain aspects of religious and community practices (Wolosky, 2009). In a culture where a significant portion of men are still required to thank God for not making them a woman (Kahn, 2010),

5 A Mehitzah is a physical partition which separates men and women in traditional ceremonies (Wolosky, 2009). 
Endean is not an objective Jewish player modulating the Torah; her womanhood is in itself disruptive, and its presence produces new understandings of how one might relate to God (Plaskow, 2003). This gendering of the Torah uncovers what is submerged in most discussions of supposedly neutral endeavours such as philosophical or scriptural inquiry; that the feminine is not one with the masculine, but always lesser, and often completely forgotten (Ziarek, 1998).

This act reminds us of the hundreds of thousands of voices excluded from, and erased by, these ceremonies. It is in direct opposition to the flattening effect of Jewish reconstructionism, Hasidic separatism, and Klezmer revivalism. It directs Judaism's movement forwards, towards egalitarianism and liberation for all, rather than backwards, towards a narrow view of tradition and disengagement from the progress being made by contemporary society in the name of preserving 'Jewish culture' (Belcove-Shalin, 1995). In many ways, this reflects the political and cultural standpoints of progressive Judaism, with its aims of eliminating sexism and racism from contemporary Jewish practice (Tobias \& Keren-Black, 2010); however, Lehadlik goes a step beyond. The work asks each viewer to uncover their place within their own traditions, and to perform what Gordon (2008) defines as a way of speaking with the ghosts which haunt every culture. This 'speaking' is beyond verbal; it is an act of uncovering tragedies and celebrations either lost or suppressed, and finding means of engaging with, and often embodying, those experiences. In prompting this dialogue between people and the ghosts of their culture, Lehadlik has the potential to facilitate a space for each attentive viewer to clearly hear old and lost voices and attune to what they ask us to do, thereby allowing these ghosts to become honoured ancestors who can live on in us (Stein, 2014).

Through this process, Lehadlik becomes more than a passive viewing of another person's engagement with their culture. It transforms into an invitation to consider alternative ways of engaging with any culture, through its multiple points of contrast and interaction: ancient and contemporary; Ashkenazi and Sephardi; 'male' - and 'female'-appropriate cultural practices; silver candle-holders and digital processors. Even for those whose lack of understanding of Judaism prevents them from comprehending the full depth of the piece, its use of technology and theatre provides ample methodological inspiration as to how one can disrupt and investigate their own traditional cultural practices. With these considerations in mind, it is important to consider the role of duality in Lehadlik.

\section{Talmudic Disidentification}

Lehadlik exists in a dichotomy. The player immerses herself in traditional rituals and sounds while simultaneously interrupting the proceedings with embodied and digital modes of questioning. This act can be described as a disidentification, a process of using the "code of the majority" as "raw material for representing a 
disempowered politics or positionality that has been rendered unthinkable by the dominant culture" (Muñoz, 1999, p. 31). Endean takes powerful words, delivered by people who are inside a very small circle of power and permission, and investigates what occurs when a body such as hers is placed within these rituals. Lehadlik is not a purely radical act, nor is it simply an act of devotion. Endean stands her ground and outwardly states her dedication to Judaism, and uses this steadfastness as a driving force for challenging current paradigms. She does not only ask herself who she is within the context of Judaism, but asks the same of Judaism within the context of an ever-evolving world.

Although this challenge to current tradition may seem like part of the contemporary paradigm of a post-feminist sociocultural landscape, in some ways Endean is enacting her own kind of historical reconstruction. Orthodox Judaism, and its fundamentalist proponents in particular, have created a culture of masculine stoicism, aggression, and in some cases violence, as a means of defending their culture (Aran, Stadler, \& Ben-Ari, 2008). However, this masculinity is relatively newfound, and throughout the history of Judaism, much of the individual and interpersonal strength and power was attributed to Jewish women, with men being encouraged to embrace emotion and gentleness (Jakobsen, 2003). This may be the final step in her disidentification: completing a cycle that is over a century in the making, reminding Judaism of its radical-yetgentle history, and re-orienting the balance of gendered rights and responsibilities. Endean's work blends what we know today with what we have known for a long time. In some ways, her presence within these rituals and traditions is not a new act: it is very, very old.

\section{Discussion}

Although Radical Jewish Music has no guidelines, Endean's Lehadlik delineates a consistent approach to undertaking the task of producing and performing music that critically engages with Judaism and its place in the world today. Her work evokes the deep introspection, textual exploration, and broad creativity which much of contemporary Jewish music, and RJM in particular, has come to express. Part of RJM is about questioning what it means to be a Jewish musician, and using the knowledge yielded from this effort to produce music that is transformative for both the player(s) and the audience. Transformation takes a particular path in Endean's work; whether it's traditional rituals, instrumentation, melody, or setting, she does not modulate anything so that its origin is no longer coherent. There is, in some ways, an act of conservation being undertaken in this work. It reminds each listener of how they are situated in relation to this work: culturally, geographically, technologically. At the same time, Lehadlik compels the audience to listen deeply, and to consider the seemingly timeless roots of the 
materials being used. In holding Jewish music at the seam between history and contemporary society, Endean shows a way to explore our cultural past while moving towards an illuminated future.

\section{References}

Aran, G., Stadler, N., \& Ben-Ari, E. (2008). Fundamentalism and the masculine body: The case of Jewish ultra-Orthodox men in Israel. Religion, 38(1), 2553. doi: 10.1016/j.religion.2007.09.002.

Avery-Peck, A., \& Neusner, J. (2004). The Routledge dictionary of Judaism (1st edition). United States: Routledge Press.

Belcove-Shalin, J. S. (1995). New World Hasidim: Ethnographic Studies of Hasidic Jews in America (1st edition). New York: SUNY Press.

Bohlman, P. V. (2013). Revival and reconciliation: Sacred music in the making of European modernity (1st edition). Lanham, Maryland; Scarecrow Press.

Charme, S. L. (2000). Varieties of authenticity in contemporary Jewish identity. Jewish Social Studies, 6(2), 133-155. doi: 10.1353/jss.2000.0001.

Cohen, N., \& Ner-David, H. (2002). "Should women be called to read the Torah in orthodox congregations?." The Jerusalem Report, May 6 2002. ProQuest.

Cushman, P. (2007). A burning world, an absent God: Midrash, hermeneutics, and relational psychoanalysis. Contemporary Psychoanalysis, 43(1), 47-88. doi: 10.1080/00107530.2007.10745896.

Eichler, J. (1997). “But Is It Jewish?”. The Jerusalem Report, November 131997. ProQuest.

Endean, A. (2015). Lehadlik (excerpt). Retrieved from https://vimeo.com/153099959.

Feldman, W. Z. (2016). Klezmer: Music, history and memory (1st edition). Oxford, United Kingdom: Oxford University Press.

Gohdes-Luhman, A. (2004). "Jezebel: Layered and leveled.” PhD Diss., Northwestern University.

Gordis, R. (1970). On methodology in biblical exegesis. The Jewish Quarterly Review, 61(2), 93-118. doi: 10.2307/1453428.

Gordon, A. F. (2008). Ghostly Matters: Haunting and the Sociological Imagination (1st edition). Minneapolis, Minnesota: University of Minnesota Press.

Hall, D. E. (2009). Reading Sexualities: Hermeneutic Theory and the Future of Queer Studies (1st edition). London: Routledge.

Jakobsen, J. R. (2003). Queers are like Jews, aren't they? Analogy and alliance politics. In D. Boyarin, D. Itzkovitz, \& A. Pellegrini (Eds.), Queer Theory 
and the Jewish Question (64-89). New York City, New York: Columbia University Press.

Jockusch, L. (2012). Collect and record!: Jewish Holocaust documentation in early postwar Europe (1st edition). Oxford, United Kingdon: Oxford University Press.

Kahn, Y. (2010). The Three Blessings: Boundaries, Censorship, and Identity in Jewish Liturgy (1st edition). United Kingdom: Oxford University Press.

Kolbrener, W. (2004). "Chiseled from all sides": Hermeneutics and dispute in the Rabbinic tradition. Association for Jewish Studies: AJS Review, 28(2), 273295. doi: 10.1017/S0364009404000170.

Levinson, B., \& Molly M. Zahn. (2002). Revelation regained: The hermeneutics of $כ$ and the Temple Scroll. Dead Sea Discoveries, 9(3), 295-346. Retrieved from http://www.jstor.org/stable/4193247.

McClary, S. (2000). Conventional wisdom: The content of musical form. Berkley, California; University of California Press.

Muñoz, J. E. (1999). Disidentifications: Queers of Color and the Performance of Politics (2nd edition). Minneapolis, Minnesota: University of Minnesota Press.

National Public Radio (NPR) (2013). Anat Cohen: Bringing the clarinet to the world. Retrieved from http://www.npr.org/2013/10/25/240552305/anatcohen-bringing-the-clarinet-to-the-world.

Noël, J. (2010). Klezmer 'Revivalisms' to the test of real or supposed cultural borders: The stakes of memory and objects of misunderstanding. Eurolimes, 9(1), 143-152 \& 197. Retrieved from https://search-proquestcom.dbgw.lis.curtin.edu.au/docview/818345491 ?accountid=10382.

Plaskow, J. (2003). Standing again at Sinai: Judaism from a feminist perspective. In R. S. Gottlieb (Ed.), Liberating faith: Religious voices for justice, peace, and ecological wisdom, Lanham, Maryland: Rowman \& Littlefield.

Rojtman, B. (1998). Black fire on white fire: an essay on Jewish Hermeneutics, from Midrash to Kabbalah (2nd edition). Berkley, California: University of California Press.

Rosenfelder, R. (2012). "Whose music? Ownership and identity in Jewish Music", Melilah 9(1), 82-90. Retrieved from https://search-proquestcom.dbgw.lis.curtin.edu.au/docview/1505321176?accountid=10382.

Runions, E. M. (2001). Reading gender, nation and future vision in Micah: Reconfiguring the reader as subject ( $\mathrm{PhD}$ dissertation). Retrieved from https://search-proquest-com.dbgw.lis.curtin.edu.au/docview/304758088? accountid=10382 (NQ70143).

Stein, A. (2014). Reluctant witnesses: Survivors, their children, and the rise of Holocaust Consciousness (1st edition). Oxford, United Kingdom: Oxford University Press. 
Stevens, P. R., \& Steinmetz, S. (2002). Meshuggenary: Celebrating the world of Yiddish (1st edition). New York City, New York: Simon \& Schuster.

Stone, I. F. (1998). Reading Levinas/Reading Talmud: An introduction (1st edition). Philadelphia, Pennsylvania: Jewish Publication Society.

Tobias, P. \& Keren-Black, J. (2010). A Judaism for the twenty-first century (1st edition). N.C.: CreateSpace.

Walden, J. (2009). Music of the "folks-neshome": "Hebrew melody" and changing musical representations of Jewish culture in the early twentieth century Ashkenazi Diaspora. Journal of Modern Jewish Studies, 8(2), 151172. doi: 10.1080/14725880902949122.

Waligorska, M. (2013). Klezmer's afterlife: An ethnography of the Jewish music revival in Poland and Germany (1st edition). Oxford, United Kingdom: Oxford University Press.

Wall, A. J. (1999). "Rhythm \& Jews", Moment, 24(1), 40-47. Retrieved from https://search-proquest-com.dbgw.lis.curtin.edu.au/docview/194479968? accountid=10382.

Wolosky, S. (2009). Foucault and Jewish feminism: The Mehitzah as dividing practice. Nashim, 17(1), 9-32. Retrieved from http://www.jstor.org/stable/10.2979/nas.2009.-.17.9.

Yanow, D. (1998). From what Edah are you? Israeli and American meanings of "race-ethnicity" in social policy practices. Israel Affairs, 5(2-3), 183-199. doi: 10.1080/13537129908719518.

Yerushalmi, Y. H. (2011). Zakhor: Jewish history and Jewish memory (4th edition). Seattle, Washington: University of Washington Press.

Yuter, A. (2010). Torah as song. Baltimore Jewish Times, 316(2), 41. Retrieved from https://search-proquestcom.dbgw.lis.curtin.edu.au/docview/753947553? accountid=10382.

Ziarek,. E. P. (1998). Toward a radical female imaginary: Temporality and embodiment in Irigaray's ethics. Diacritics, 28(1), 60-75. Retrieved from http://www.jstor.org/stable/1566324.

Zorn, J. (2006). Radical Jewish Culture. Retrieved from http://tzadik.com/rjc_info.html. (2007). John Zorn - An informance with John Zorn, 2007. Retrieved from https://www.youtube.com/watch?v=Jj0M8HdGGgE. 